\title{
The Investigation of Phytochemical Contains, Antioxidant and Antimicrobial Activities of Malus floribunda Siebold ex Van Houtte From Eastern TURKEY
}

\author{
Sevda Kırbağ, Duygu Aydoğan \\ Department of Biology, Faculty of Sciences, Fırat University, TR 23119, Elazığ - TURKEY.
}

\begin{abstract}
Objective: $M$. floribunda is an ornamental and landscape plant in Turkey and it's small fruits are consumed as food. Antimicrobial, antioxidant activities and phytochemical contents of $M$. floribunda were investigated. Material and Method: $M$. floribunda was collected from different localities in the province of Elazig-Turkey. The nutritive value (flavonoid, sugar, fatty acid, vitamin, protein, element), antioxidant (lipid peroxidation, glutathione amounts and DPPH) and antimicrobial activities (on thirteen bacteria, three yeast and two dermatophyte) of $M$. floribunda were determined. Results: Vitamin (1.73$3.5 \mu \mathrm{g} / \mathrm{g} \mathrm{A}, 1.32-1.44 \mu \mathrm{g} / \mathrm{g} \mathrm{D}, 2.75-2.83 \mu \mathrm{g} / \mathrm{g} \mathrm{E}, 2.64-3.30 \mu \mathrm{g} / \mathrm{g} \mathrm{K}$ ), flavonoid (33-253 $\mu \mathrm{g} / \mathrm{g}$ routine, 93-123 $\mu \mathrm{g} / \mathrm{g}$ morin, 0.22-0.32 $\mu \mathrm{g} / \mathrm{g}$ quercetin, 292-356 $\mu \mathrm{g} / \mathrm{g}$ naringenin), sugar $(97-820 \mu \mathrm{g} / \mathrm{g})$, protein (1.4-1.6 $\mu \mathrm{g} / \mathrm{g}$ ) and phytosterol $(0.27-1.74 \mu \mathrm{g} / \mathrm{g}$ ergosterol, 26-36 $\mu \mathrm{g} / \mathrm{g}$ stigmasterol, 95-121 $\mu \mathrm{g} / \mathrm{g} \beta$-sitosterol and $0.21-0.35 \mu \mathrm{g} / \mathrm{g}$ retinol) levels can vary. In vitro medium, it is determined that in $\mathrm{FeCl}$ group, LPO amounts increases in a large ration with respect to the control group and LPO levels in groups which includes plant extracts and $\mathrm{FeCl}_{2}$, decreases in certain amounts. It was determined that the radical scavenging activity of the fruits increased due to the dose. Four different fatty acids were identified in the fruit. Fruits were found to different levels of sugar. Vitamin $E$ in the examples were determined high rate. Protein found up to $1.686 \mathrm{mg} / \mathrm{g}$. Ca content was the most detected in the all samples. Extracts inhibited the development of microorganisms at different rates. Conclusion Although studies on this type were limited, similarities and differences were seen in the results compared to other studies.
\end{abstract}

Key words: M. Floribunda, Flavonoids, Phytosterol, Apple, Antioxidant Effect, Antimicrobial Activities.

\section{INTRODUCTION}

Apples contains are phytochemicals which potent antioxidant and antimicrobial activity. The majority of these phytochemicals consist of phenolic compounds. ${ }^{1}$ Flavonoids from the phenolic components of apple are quercetin and glycosides. ${ }^{2}$ In addition to antimutagenic and potent antioxidant effects of M. domestica and its juice, it has been determined to be protective against to cancer, diabetes, obesity, cardiovascular diseases, asthma and other lung diseases. ${ }^{3}$ Apple consumption has been found to reduce the risk of colorectal cancer. This effect was thought to be due to was rich in flavonoid and other polyphenol contents. $^{4}$

M. floribunda is an ornamental and landscape plant in Turkey and small fruits are consumed as food. Especially, this fruit is consumed by diabetic patients as a sugar reducing agent in Elazığ, Turkey. In this study, medicinal (antimicrobial and antioxidant) effects and phytochemical contents of $M$. floribunda was investigated.
DOI: 10.5530/ijper.51.3s.45 Correspondence: Sevda Kirbag, Department of Biology, Faculty of Sciences, Firat University, TR 23119, Elaziğ - TURKEY

Phone no: +90424-2370000 - 3815

E-mail: skirbag@firat.edu.tr

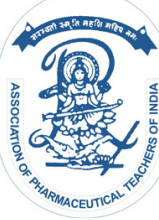

www.ijper.org 


\section{MATERIAL AND METHOD}

\section{Fruit Samples}

M. floribunda was collected from different regions of Elazığ, placed in sterile bags and kept refrigerated at $-20{ }^{\circ} \mathrm{C}$ until analysis.

\section{Preparation of Fruits Extracts}

Fruit samples were extracted at a ratio of $1: 5(\mathrm{~g} / \mathrm{mL})$ with methanol. After blotting, all groups were centrifuged. The supernatant obtained at the end of centrifugation was removed from the solvent medium using rotovapor. Methanol was added to prepare an extract.

\section{Determination of resveratrol and flavanoid content}

Analysis of the flavanoid and resveratrol were performed on a HPLC with according to the method determined by Rodriguez-Delgado et al. ${ }^{5}$

\section{Extraction and Analysis of Phytosterols and ADEK Vitamins}

Fruit was weighed and homogenized with a $3 / 2$ mixture of hexane/isopropyl alcohol and after hydrolysis at $85^{\circ} \mathrm{C}$ with $5 \% \mathrm{KOH}$, extractions of phytosterols were done with $\mathrm{n}$-heptane. Fruit extracts were prepared according to the litterature to determine the amount of vitamins. The content of phytosterol and vitamins were analyzed by HPLC. 6,7

\section{Free Radical (DPPH) Activity}

Free radical $25 \mathrm{mg} / \mathrm{l} \mathrm{DPPH}$ methanol was prepared. $10,25,50$ and $100 \mu \mathrm{g} / \mu \mathrm{l}$ extracts and $3.9 \mathrm{ml} \mathrm{DPPH}$ solution were added to the test tubes, respectively. The mixtures were allowed to incubate for 30 minutes at room temperature in a dark place, and the absorbance at $517 \mathrm{~nm}$ was read on a spectrophotometer against blanks at the end of the incubation. ${ }^{8}$ The reduced absorbance, the amount of DPPH remaining, was determined as the free radical scavenging activity. The results were calculated according to the following formula: $\%=[$ (Contro$1_{\mathrm{ABS}}-$ Sample $\left._{\mathrm{ABS}}\right) /$ Control $\left.\left._{\mathrm{ABS}}\right)\right] * 100.6 \mathrm{~mm}, 5 \mu$.) Column.

\section{Lipid Peroxidation (LPO) Measurement In vitro}

After taking $1 \mathrm{ml}$ of the sample, $1 \mathrm{ml}$ of TBA solution of $0.6 \%, 1 \mathrm{ml}$ of TCA solution of $20 \%, 1 \mathrm{ml}$ of $4 \%$ $\mathrm{HCI}$ and $1 \mathrm{ml}$ of distilled water was added and vortexed. It was then incubated at $95^{\circ} \mathrm{C}$ for $60 \mathrm{~min}$. and the resulting pink color was extracted with $3 \mathrm{~mL}$ of n-butanol. Samples were centrifuged and the supernatant fraction obtained at the end of centrifugation was read spectrophotometrically at a wavelength of $532 \mathrm{~nm}$ against to blanka. 1,1,3,3-Tetraethoxypropane (TEP) was used as standard and the readings were calculated according to calibration curve. The results were given in $\mathrm{nmol} / \mu \mathrm{l}$.

\section{Determination of Element Contents}

The samples were dried at room temperature for about 2 week, then grinded and stored at $105^{\circ} \mathrm{C}$ for 24 hours. $1 \mathrm{~g}$ samples was weighed out and $10 \mathrm{~mL}$ of a mixture of $\mathrm{HNO}_{3}: \mathrm{H}_{2} \mathrm{SO}_{4}: \mathrm{H}_{2} \mathrm{O}_{2}$ (10:1:1) was added. The samples were incubated at $100^{\circ} \mathrm{C}$ until dissolved. Then the $\mathrm{dH}_{2} \mathrm{O}$ was added to the cooled samples as $50 \mathrm{~mL}$ and filtered with filter paper. The element contents of the samples were determined by atomic absorption and atomic emission spectrophotometer. ${ }^{9}$

\section{Measurement of Protein Amount}

The total protein level of the fruits were determined spectrophotometrically at $750 \mathrm{~nm}$ using a commercial kit. ${ }^{10}$

\section{Antimicrobial activity \\ Preparing Extracts}

Plant groups were extracted with methanol at a ratio of $1 / 10(\mathrm{~g} / \mathrm{ml})$. Fruits extracts were stored at $+4^{\circ} \mathrm{C}$ during experimental runs.

\section{Preparation of microorganism cultures}

Bacterial strains (Listeria monocytegenes, Salmonella enterica typhimirium, Enterococcus faecium, Proteus mirabilis, Staphylococcus cohnii, Staphylococcus aureus COWAN 1, Bacillus megaterium DSM32, B. subtilis, Klebsiella pneumoniae FMC 5, Escherichia coli ATCC 25922, Proteus vulgaris FMC1, Enterobacter aeregenes CCM 2531, Pseudomonas aeruginosa DMS50071) and yeast (Candida albicans FMC17, C. glabrata ATCC 66032, C. tropicalis ATCC1380, Trichophyton sp. and Epidermophyton sp.) in nutrient buyyon and malt extract was inoculated, respectively ( 48 hours at $25 \pm 1^{\circ} \mathrm{C}$ for yeast, $24 \mathrm{~h}$ at $35 \pm 1^{\circ} \mathrm{C}$ for bacteria).

\section{Disc Diffusion Method}

The impregnated discs were placed on the solidified agar by lightly pressing. Petri dishes prepared in this manner were incubated at $4^{\circ} \mathrm{C}$ for $1.5-2 \mathrm{~h}$, then incubated for $24 \mathrm{~h}$ at $37 \pm 1^{\circ} \mathrm{C}$ with bacteria-inoculated plates and plates at yeast and dermophyte-grafted plates at $25 \pm 1^{\circ} \mathrm{C}$ for 3 days. The inhibition zones $(\mathrm{mm})$ formed on the feeder at the end of the period were evaluated. Standard antibiotic discs were used for control group. The antimicrobial activity test was repeated three times.

\section{Statistical analysis}

For statistical analysis, SPSS 15.0 for Windows package program was used. Comparison between control and experimental groups was performed using One way ANOVA and LSD tests. The results were expressed as mean \pm SEM. The differences between the groups were $\mathrm{p}>0.05, \mathrm{p}<0.05, \mathrm{p}<0.01, \mathrm{p}<0.001$ and $\mathrm{p}<0.0001$. 


\section{RESULTS}

\section{Flavonoid and Resveratrol Contents of Fruit}

Routine, morin, quercetin, naringenin were found in all samples. Routine was determined the most in A1, the lowest in the A2 ( $>0.05)$ show Table 1. Also, morin was determined the most A1. Quercetin was found to be less than other flavonoids. Naringenin was found more than other flavonoids but A1.

\section{Phytosterol Contents of Fruit}

Ergosterol, stigmasterol, $\beta$-sitosterol and retinol were found in all groups. $\beta$-sitosterol was determined the most abundant phytosterol. Ergosterol was determined to be highest in A1 group and lowest in A2. Stigmasterol was found to be most abundant in $\mathrm{A} 2$, but retinol was found to be less than other phytosterols $(\mathrm{p}>0.05)$ (Table 2).

\section{Vitamin Content of Fruits}

Vitamin A was determined the highest in A1, but lowest in A3. The amount of vitamin $D$ in all samples was determined to be the lowest ( $\mathrm{p}>0.05$ ) (Table 3).

\section{Sugar Contents of Fruit}

Fructose, glucose, sucrose and maltose were found to be common in all groups. Sucrose was determined as the most abundant sugar while maltose was determined the lowest $(\mathrm{p}>0.05)$ see in Table 4.

\section{The Effect of Scavenging DPPH Radicals of M. floribunda}

It was determined that the effect of free radical scavenging (DPPH) increased with parallel to increasing amount of concentration of fruit extract (Figure 1). When the concentration-dependent radical scavenging effect of the fruit sample was compared statistically. The difference between $50 \mu \mathrm{L}-100 \mu \mathrm{L}$ and $100 \mu \mathrm{L}-200 \mu \mathrm{L}$ was not significant ( $\mathrm{p}>0.05)$. In addition, the activity at $5 \mu \mathrm{L}$ and $25 \mu \mathrm{L}$ concentrations was significantly lower than the other concentrations $(\mathrm{p}<0.05)$ see Figure 1.

\section{In vitro Antioxidant Effects (LPO) of M. floribunda}

Lipid oxidation level was significantly increased in all groups compared to the control group show Figure 2 $(\mathrm{p}<0.05)$. There was a significant decrease in lipid oxidation level in fruit groups $(\mathrm{p}<0.05)$. When samples collected from different localizations were compared among themselves. No difference was observed between A2 and A3 ( $>>0.05)$, whereas A1 was found to be less effective $(\mathrm{p}<0.05)$ compared to those two examples see Figure 2.

\begin{tabular}{|c|c|c|c|}
\multicolumn{5}{|c|}{ Table 1: Flavonoid and resveratrol content of } \\
M. floribunda $(\boldsymbol{\mu g} / \mathbf{g})$ \\
\hline Flavonoid & A1 & A2 & A3 \\
\hline Routine & $253.05 \pm 2.8$ & $33.55 \pm 1.63$ & $103.95 \pm 1.59$ \\
\hline Morin & $123.7 \pm 5.22$ & $103.05 \pm 5.06$ & $93.48 \pm 2.28$ \\
\hline Quercetin & $0.22 \pm 0.26$ & $0.30 \pm 0.1$ & $0.32 \pm 0.3$ \\
\hline Naringenin & $352.9 \pm 4.02$ & $292.11 \pm 2.61$ & $356.16 \pm 3.4$ \\
\hline Kamferol & - & - & - \\
\hline Myricetin & - & - & - \\
\hline Resveratrol & - & - & - \\
\hline
\end{tabular}

Mean \pm SD (n=3). A1: lokal. 1, A2: lokal. 2, A3: lokal. 3.

Table 2: Phytosterol content of $M$. floribunda $(\mu \mathrm{g} / \mathrm{g})$

\begin{tabular}{|c|c|c|c|}
\hline Phytosterol & A1 & A2 & A3 \\
\hline Ergosterol & $1.74 \pm 0.06$ & $0.27 \pm 0.02$ & $0.89 \pm 0.04$ \\
\hline Stigmasterol & $28.96 \pm 0.49$ & $36.61 \pm 1.16$ & $26.71 \pm 1.93$ \\
\hline$\beta$-sitosterol & $121.7 \pm 2.67$ & $102.8 \pm 1.71$ & $95.6 \pm 0.71$ \\
\hline Retinol & $0.35 \pm 0.04$ & $0.27 \pm 0.03$ & $0.21 \pm 0.03$ \\
\hline
\end{tabular}

$P>0.05$, Mean $\pm S D(n=3)$.

\begin{tabular}{|c|c|c|c|}
\hline \multicolumn{4}{|c|}{ Table 3: Vitamin levels of M. floribunda collected } \\
from different localities $(\boldsymbol{\mu g} / \mathbf{g})$
\end{tabular}

$P>0.05$, Mean $\pm S D(n=3)$. A1: lokal. 1, A2: lokal. 2, A3: lokal. 3

\section{Table 4: Sugar Contents of M. floribunda}

\begin{tabular}{|c|c|c|c|}
\hline Sugar & A1 & A2 & A3 \\
\hline Fructose & $453.5 \pm 7.99$ & $450.68 \pm 6.93$ & $460.75 \pm 19.74$ \\
\hline Glucose & $340.58 \pm 5.68$ & $236.10 \pm 19.43$ & $356.71 \pm 17.8$ \\
\hline Sucrose & $820.74 \pm 19.9$ & $826.13 \pm 22.5$ & $824.54 \pm 3.49$ \\
\hline Maltose & $97.75 \pm 15.17$ & $112.63 \pm 7.51$ & $98.65 \pm 2.21$ \\
\hline
\end{tabular}

$P>0.05$, Mean $\pm S D(n=3)$. A1: lokal. 1. A2: lokal. 2. A3: lokal. 3.

\begin{tabular}{|c|c|c|c|}
\hline \multicolumn{4}{|c|}{ Table 5: Effect of $\begin{array}{c}\text { M. floribunda on methyl esters } \\
\text { in vitro }(\boldsymbol{\mu m o l} / \mathbf{~} \mathbf{l})\end{array}$} \\
\hline $\begin{array}{c}\text { Methyl } \\
\text { esters }\end{array}$ & A1 & A2 & A3 \\
\hline $16: 00$ & $37.5 \pm 0.98$ & $58.4 \pm 3.17$ & $60.7 \pm 1.36$ \\
\hline $18: 00$ & $20.19 \pm 0.77$ & $13.92 \pm 1.73$ & $27.13 \pm 1.49$ \\
\hline $18: 01$ & $15.39 \pm 0.94$ & $24.73 \pm 2.81$ & $27.13 \pm 1.48$ \\
\hline $18: 03$ & $50.11 \pm 1.68$ & $36.95 \pm 1.67$ & $54.44 \pm 2.31$ \\
\hline $24: 01$ & $150 \pm 2.93$ & $96.19 \pm 2.44$ & $122.31 \pm 1.92$ \\
\hline
\end{tabular}

The results were given as mean $\pm S D(n=3)$. A1: local. 1. A2: local. 2. A3: local. 


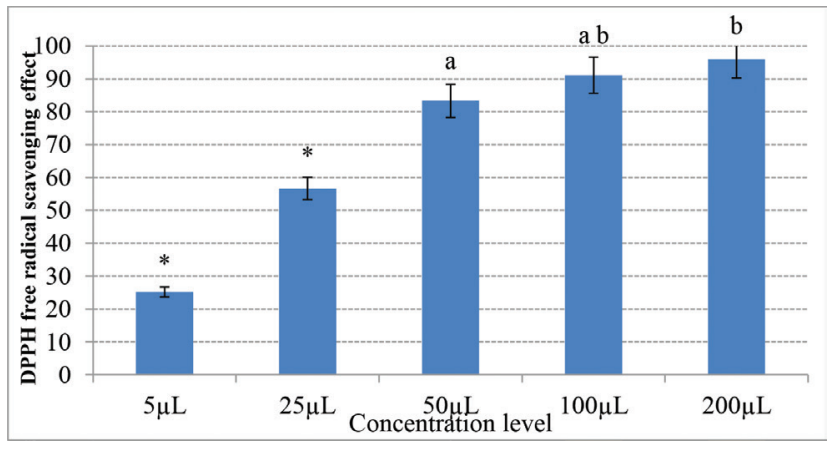

Figure 1: DPPH free radical scavenging effect (\%) depending on the increasing concentration level of $M$. floribunda.

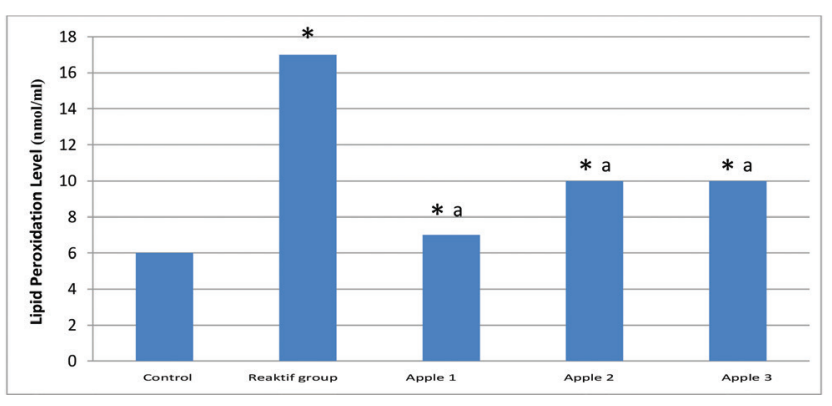

Figure 2: In vitro lipid peroxidation inhibition level M. floribunda. (The results were given as mean $\pm S D(n=3)$. A1: loc.1. A2: loc. 2. A3: loc.3.* $p<0.05$ compared to other groups. ${ }^{a} p<0.05$ compared to reactive group.

Table 6: Protein amount of M. floribunda

\begin{tabular}{|c|c|}
\hline Samples & Amount of protein \\
\hline A1 & $1.412 \pm 0.35$ \\
\hline A2 & $1.686 \pm 0.26$ \\
\hline A3 & $1.611 \pm 0.62$ \\
\hline
\end{tabular}

\begin{tabular}{|c|c|c|c|}
\hline \multicolumn{4}{|c|}{ Table 7: Element amounts of M. floribunda } \\
\hline Minerals & A1 & A2 & A3 \\
\hline $\mathrm{Cu}$ & $8.44 \pm 0.14$ & $8.49 \pm 0.16$ & $9.70 \pm 0.11$ \\
\hline $\mathrm{Zn}$ & $5.28 \pm 0.17$ & $4.78 \pm 0.23$ & $4.50 \pm 0.27$ \\
\hline $\mathrm{Mn}$ & $4.80 \pm 0.19$ & $5.00 \pm 0.14$ & $4.45 \pm 0.22$ \\
\hline $\mathrm{Fe}$ & $28.56 \pm 1.14$ & $25.51 \pm 1.19$ & $24.45 \pm 1.28$ \\
\hline $\mathrm{Ca}$ & $101.4 \pm 2.1$ & $90.60 \pm 1.93$ & $85.43 \pm 1.86$ \\
\hline $\mathrm{Mg}$ & $80.0 \pm 1.67$ & $72.67 \pm 1.78$ & $75.56 \pm 1.70$ \\
\hline
\end{tabular}

Mean $\pm S D(n=3)$.

\section{Effects of $M$. floribunda on Fatty Acid Methyl Esters in vitro}

Palmitic acid, stearic acid, oleic acid, linolenic acid and nervonic acid were determined in 3 group (Table 5). When palmitic acid (16:00) was examined in fruit extract groups, there was no statistically significant difference in A2 and A3 ( $>>0.05)$, but decrease in A1 $(p<0.05)$. Stearic acid (18:00) showed the highest difference between

\begin{tabular}{|c|c|c|c|c|}
\hline \multicolumn{5}{|c|}{ Table 8: Antimicrobial Activities of M. floribunda } \\
(mm diam.) \\
Microorganism & $\begin{array}{c}\text { Apple } \\
\text { juice }\end{array}$ & $\begin{array}{c}\text { Apple } \\
\text { juicer + } \\
\text { metanol }\end{array}$ & $\begin{array}{c}\text { Apple } \\
\text { pulp }\end{array}$ & Standart \\
\hline L. monocytogenes & 23 & 15 & 15 & 15 \\
\hline S. enterica & 20 & 20 & 26 & 20 \\
\hline E. faecium & 23 & 20 & 25 & 15 \\
\hline P. mirabilis & 20 & 22 & 20 & 20 \\
\hline S. cohnii & 20 & 15 & 22 & 10 \\
\hline S. aureus & 20 & 20 & 25 & 15 \\
\hline B. megaterium & 25 & 22 & 25 & 20 \\
\hline B. subtilis & 22 & 20 & 20 & 15 \\
\hline K. pneumoniae & 18 & 16 & 20 & 12 \\
\hline E. coli & 20 & 20 & 20 & 15 \\
\hline E. aeregenes & 22 & 20 & 20 & 15 \\
\hline P. aeroginosa & 23 & 15 & 18 & 17 \\
\hline C. albicans & 22 & 17 & 20 & 12 \\
\hline C. glabrata & 18 & 15 & 20 & 15 \\
\hline C. tropicalis & 15 & 17 & 22 & 15 \\
\hline Epidermaphyton spp. & 23 & 20 & 23 & 17 \\
\hline Trichophyton spp. & 22 & 18 & 23 & 15 \\
\hline & & & & \\
\hline
\end{tabular}

groups, while A3 had the least A2 ( $<<0.05)$. The amount of oleic acid (18:1) was determined different in fruit extract groups. The highest effect was found in A3 with the least effect in A1. Linolenic acid (18:3) showed the highest effect in A3, showing the least effect in A2. Nervonic acid (24:1) was determined the highest in A3 (Table 5).

\section{Protein Amounts of M. floribunda}

The highest protein level was determined in A2 see in Table 6. There was no statistically significant difference between these 2 groups ( $p>0.05)$. The low amount of protein was observed in $\mathrm{A} 1$ and decreased in the other 2 groups $(\mathrm{p}<0.05)$.

\section{Determination of Mineral Element Content of M. floribunda}

The amount of $\mathrm{Ca}$ was detected most in all samples. $\mathrm{Mn}$ was found to be at least (see Table 7).

\section{Antimicrobial Activities of M. floribunda}

It was determined that the extract inhibited the growth of all bacteria, yeast and dermatophyte fungi. The apple juices showed the most antimicrobial effect in B. megaterium $(25 \mathrm{~mm})$. The fruits juices + methanol showed the most antimicrobial effect to $P$. mirabilis (22 $\mathrm{mm})$ with inhibition zone diam. The maximum effect was shown in $S$. enterica typhimirium $(26 \mathrm{~mm})$, E. faecium $(25 \mathrm{~mm})$, S. aureus $(25 \mathrm{~mm})$ and B. megaterium $(25 \mathrm{~mm})$ see in Table 8. 


\section{DISCUSSION}

The major flavonol glycosides identified in the golden apple bark are quercetin-3-galactoside, quercetin-3glucoside, quercetin-3-xyloside, quercetin-3-arabinoside, quercetin-3-rhamnoside and the routine. ${ }^{11}$ In addition to quercetin glycosides and floridzin and phloretin glycosides was detected in the spartan and greening apple bark. ${ }^{12,13}$ Four anthocyanins, three quercetins, two phenolic acids, two flavan 3-ols and one dihydrochalcone glycoside were found in the apple variety of Skugog. ${ }^{14}$ During cold storage, after storage, ripening and intermittent heating have been determined to affect the amount of phytosterol. ${ }^{15}$ It was determined $7 \mu \mathrm{g}$ of total vitamin with consist of $0.5 \mathrm{mg}$ vitamin $\mathrm{E}, 4 \mu \mathrm{g}$ vitamin $\mathrm{K}$, $11.0 \mathrm{mg}$ vitamin $\mathrm{C}, 0.2 \mathrm{mg}$ niacin and $6 \mu \mathrm{g}$ folic acid in 100 gr apple (ww). ${ }^{16}$ Fructose, sucrose, galactose, $\alpha$-glucose, $\beta$-glucose and sorbitol were detected in apple fruit samples. Among the existing sugars, fructose was found the most abudance, this was followed by sucrose, $\beta$-glucose, $\alpha$-glucose, galactose and sorbitol. ${ }^{17}$ Golden apple was found to be most fructose, it was also contain hight level in the mature apple. ${ }^{18,19}$ Highest DPPH activity was determined of apple bark $(92 \%) .{ }^{20}$ Oleic acid were detected in the surface wax of apple fruit. ${ }^{21}$ Amounts of protein for $100 \mathrm{~g}$ apple, it was found $0.3 \mathrm{~g}$ in wet apple, $0.3 \mathrm{~g}$ in apple juice and $1.8 \mathrm{~g}$ in dry apple. ${ }^{16}$ The total amount of protein in apple juice was found $0.07 \mathrm{~g}$ while the amount of protein in the mature apple was found to be $0.3 \mathrm{~g} .{ }^{3}$ The minerals found in apple and apple juice are 144-116 g K, 7.0-4.2 g Ca, 6.0-6.9 g Mg and 12.0-7.0 g P, respectively. ${ }^{3}$ Seventeen herbal essential oils were used against to E. coli, S. enterica and apple juice was found most active compound. ${ }^{22} M$. domestica has been found to inhibit the growth of E. coli, B. cereus and $S$. aureus too much. ${ }^{23} M$. balliana was found to be effective particularly on B. subtilus and E. coli. ${ }^{24}$ When the results of this study were compared with other studies, similar or different results were obtained (Table 1-8, Figure 1-2). It has been determined that harvesting time, maturation, cold storage, storage conditions affect the amount of phytochemical. ${ }^{15}$ It was determined that the environmental parameters can be similar or can change based on the geographical location, the area where the species were collected from the altitude, the time period of measurement and the season. All our studies comply with the observations and results of the research mentioned above, and it is especially important that the nutritive and medicinal characteristics of the M. floribunda that the other fruit types grow can vary (Table 1-8, Figure 1-2). In conclusion, it has been determined that $M$. floribunda is rich from the point of view of phytosterol, vitamin (A, D, E, K), protein, unsaturated fatty acids such as linolenic, oleic and palmitic acid, and especially flavonoid such as naringenin, routine, morin and quercetin, and also elements contests (Table 1-7). Edible M. floribunda fruits are an excellent food that can be used in a well-balanced diet for their functional compounds, and other nutritional values (Table 1-7) and medicinal effect such as antioxidant and antimicrobial effects (Figure 1-2 and Table 8).

\section{ACKNOWLEDGMENT}

We thank Prof. Dr. Ökkeş Yllmaz for technical support.

\section{CONFLICT OF INTEREST}

None

\section{ABBREVIATION USED}

HPLC: High Performance Liquid Chromatography; KOH: Potassium hydroxide; DPPH: free radical scavenging activity; TBA: Thiobarbituric acid; TCA: Trichloroacetic acid; HCI: Hydrochloric acid; TEP: 1,1,3,3-Tetraethoxypropane; $\mathrm{HNO}_{3}$ : Nitric acid; $\mathrm{H}_{2} \mathrm{SO}_{4}$ : Sulfiric acid; $\mathrm{H}_{2} \mathrm{O}_{2}$ : Hydrogen peroxide; $\mathrm{dH}_{2} \mathrm{O}$ : Distilled Water; LPO: Lipid Peroxidation; $\mathrm{FeCl}_{2}$ : ferrozine, ferrous chloride; SPSS: Statistical Package for the Social Sciences; ANOVA: Analysis of Variance; LSD: Least Significant Difference; SD: standard deviation.

\section{REFERENCES}

1. Boyer J, Liu R. Apple phytochemicals and their health benefits. Nutr J. 2004;3(1):1-15.

2. Drogoudi DP, Michailidis Z, Pantelidi G. Peel and flesh antioxidant content and harvest quality characteristics of seven Apple cultivars. Sci Hortic. 2008;115(2):149-53.

3. Gerhauser C. Cancer chemopreventive potential of apples, apple juice and apple components. Planta Med. 2008;74(13):1608-24.

4. Jedrychowski W, Maugeri U, Pac A, Sochacka-Tatara E, Galas A. Reduced risk of colorectal cancer and regular consumption of apples: hospital based case-control study in Poland. Cent Eur J Med. 2009;4(3):320-6.

5. Rodríguez-Delgado MA, Malovaná S, Pérez JP, Borges T, García MF. Separation of phenolic compounds by high-performance liquid chromatography with absorbance and fluorimetric detection. J Chrom. 2001;912:249-7.

6. Katsanidis E, Addis PB. Novel HPLC analysis of tocopherols and cholesterol in tissue. Free Radic Biol Med. 1999;27(11):1137-40.

7. Lo'pez-Cervantes J, Sanchez-Machado DI, Ri'os-Vazquez NJ. Highperformance liquid chromatography method for the simultaneous quantification of retinol, alpha-tocopherol and cholesterol in shrimp waste hydrolysate. J Chrom. 2006;1105:135-9.

8. Brand-Williams W, Cuvelier ME, Berset C. Use of a free radical method to evaluate antioxidant activity. LWT-Food Sci Technol. 1995;28(1):25-0.

9. Helrich K. Official methods of analysis of association of the official analytical chemists. USA: Published by the Association of Official Analytical Chemists Inc. Wilson Boulevard Ailington Virginia; 1990.

10. Lowry $\mathrm{OH}$, Rosenbrough NJ, Farr AL, Randall RJ. Protein measurement with the folin-phenol reagent. J Biochem 1951;193:265-77.

11. Tueber H, Herrman K. Die phenolisehen Inhaltsstoffe des Obstes: Flavonolglykoside der Aepfel (Malus silvestris Mili). ZLUF. 1978;166:80-4. 
12. Dick AJ, Redden PR, Demarco AC, Lidster PD, Grindley TB. Flavonoid glycosides of Spartan apple peel. J Agric Food Chem. 1987;35(4):529-31.

13. Oleszek E, Lee CY, Jauorski AW, Price KR. Identification of some phenolics compounds in apples. J Agric Food Chem. 1988;36(3):430-2

14. Mazza G, Velioğlu YS. Anthocyanins and other phenolic cornpounds in fruits of red-flesh apples. Food Chem. 1992;43(2):113-7.

15. Rudell DR, Buchanan DA, Leisso RS, Whitaker BD, Mattheis JP, Zhu Y, et al. Ripening, storage temperature, ethylene action and oxidative stress alter apple peel phytosterol metabolism. Phytochem. 2001;72(11):1328-40.

16. Küçükkömürler $S$, Karakuş SŞ. Elma, sağlık ve kültür. Tarim Bilim Araş Derg. 2009;2:183-6.

17. Mordoğan N, Ergun S. Golden ve starking elma çeşitlerinin şeker içerikleri ve bitki besin elementleri ile olan ilişkileri. Ege Üniv Ziraat Fak Derg. 2002;39(1):103-10.

18. Neubeller J, Buchloh G. Zuckerbestimmung in Gartenbauprodukten im Hinblick auf die Qualitatsbildung. Mitt Klosterneubg. 1975:423-32.

19. Zunxing Z, Sun YH, Huang HC, Zhao ZX. Research of soluble sugars and organic acids in apples of Shandong. J Shandong Agric Univ. 1995;26(3):355-60.
20. Khan HMS, Akhtar N. Determination of antioxidant activity and total anthocyanin contents of extracts from pulp and peel of malus domestica. Asian J Chem. 2012;24(6):2829-30.

21. Verardo G, Pagani E, Geatti P, Martinuzzi P. A thorough study of the surface wax of apple fruits. Anal Bioanal Chem. 2003;376(5):659-67.

22. Friedman M, Henika PR, Levin CE, Mandrell RE. Antibacterial activities of plant essential oils and their components against Escherichia coli O157:H7 and Salmonella enterica in apple juice. J Agric Food Chem. 2004;52(19):6042-8.

23. Fratianni F, Coppola R, Nazzaro F. Phenolic composition and antimicrobial and antiquorum sensing activity of an ethanolic extract of peels from the apple cultivar annurca. J Med Food. 2011;14(9):957-63.

24. Wen G. Bioactive metabolites from Alternaria brassicicola ML-P08, an endophytic fungus residing in Malus halliana. World $\mathrm{J}$ Microbiol Biotechnol. 2009;25(9):1677-83.

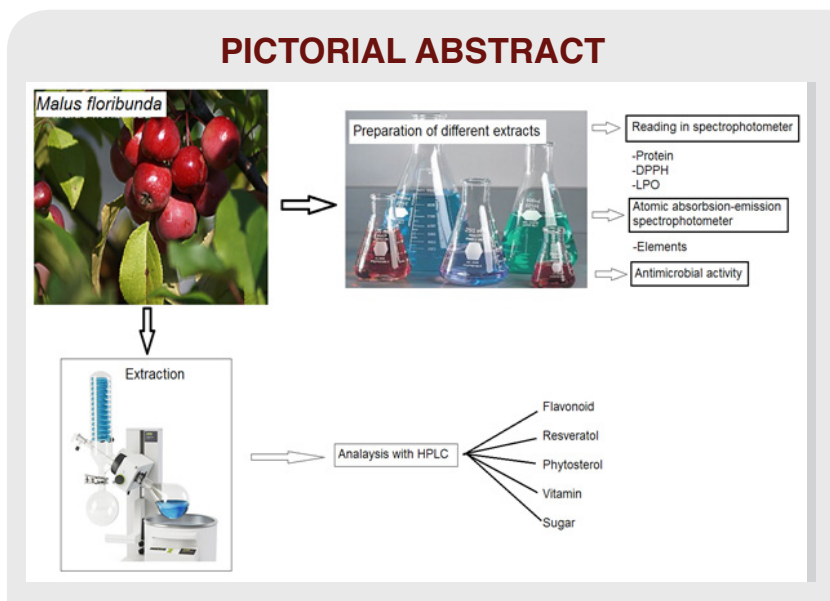

About Authors

\section{SUMMARY}

- The aim of this research is to extend our knowledge on nutritive value and medicinal (antimicrobial and antioxidant) effects of $M$. floribunda within Eastern Turkey.

- It was seen that the flavonoid, sugar, fatty acid, vitamin, protein, element levels can vary. It is rich from the point of view of phytosterol, vitamin (A, D, E, K), protein, unsaturated fatty acids, flavonoid and also elements contests.

- Edible fruits are an excellent food that can be used in a well-balanced diet for their functional compounds, and medicinal effect such as antioxidant and antimicrobial effects.

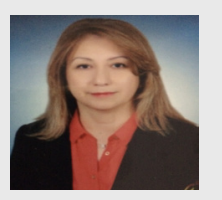

Dr. Sevda Kırbağ is presently working as Professor at the Department of Biology, Faculty of Sciences, Fırat University, Elazığ - Turkey. Her studies mainly focused on microbiology and mycology.

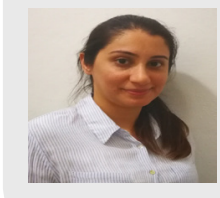

Mrs. Duygu Aydoğdu: She completed her BSc in Biology at Fırat University, Turkey. She then earned her MSc degree from the same university, completed her MSc education under the advisor of Prof. Sevda Kırbag.

Cite this article: Kirbag S, Aydogan D. The Investigation of Phytochemical Contains, Antioxidant and Antimicrobial Activities of Malus floribunda Siebold ex Van Houtte From Eastern TURKEY. Indian J of Pharmaceutical Education and Research. 2017;51(3)Suppl:S349-54. 